\title{
Syrian Refugees in the Turkish Labour Market: A Socio-Economic Analysis'
}

Luis PINEDO-CARO (https://orcid.org/0000-0003-1448-4707), International Labour Organization, Switzerland; e-mail: pinedo@ilo.org

\section{Türkiye’de İşgücü Piyasasında Suriyeli Mülteciler: Sosyoekonomik Bir Analiz $^{2}$}

\begin{abstract}
This article explores the socio-economic conditions of Syrian refugees in Turkey with the help of the Household Labour Force Survey. Firstly, it describes and analyses some of the challenges derived from an expansive population pyramid, low school attendance rates and high labour market attachment from an early age. Then, it assesses the employment and wage structure of Syrian workers, including the estimation of returns to schooling and a test for employer discrimination towards Syrian refugees. On the one hand, the results suggest that refugees are not discriminated against comparable Turkish employees. On the other hand, for Syrians with university degrees, informal work arrangements and lack of prior learning recognition make their return to schooling five times lower than that of formally employed Turkish citizens.
\end{abstract}

Keywords

Syrian Refugees in Turkey, Working Conditions, Living Conditions.

JEL Classification Codes : J21, J31, J61.

\section{Öz}

Bu çalışmada Türkiye'deki Suriyeli mültecilerin sosyo-ekonomik koşulları araştırılmaktadır. Araştırmada TÜİK'in Hanehalkı İşgücü Anketlerinden yararlanılmıştır. Öncelikle Türkiye'deki kalabalık Suriyeli nüfusun çocuk yaşlardan itibaren okula gitmek yerine çalışma hayatına yönelmesinden kaynaklanan sorunlar analiz edilmiştir. Sonrasında ise mültecilerin işyerindeki durumu, ücretleri, aldıkları eğitimin işgücü piyasasındaki getirisi ve işveren tarafından ayrımcılığa maruz kalıp kalmadıkları değerlendirme konusu yapılmıştır. Araştırmanın sonuçları mültecilerin benzer özelliklerdeki Türk çalışanlar ile kıyaslandıklarında ayrımcılığa maruz kalmadıklarına işaret etmektedir. Ancak üniversite mezunu Suriyelilerin diploma tanınırlı̆̆ının bulunmaması ve iş yerinde kayıt dışı çalışmaları nedeniyle, aldıkları eğitimin işgücü piyasasındaki getirisi Türk çalışanlara göre beşte bir düzeyindedir.

1 The author would like to thank Varol Dur and the Program of Support for Refugees'team of the ILO office in Turkey for useful comments on earlier versions of this manuscript. The suggestions from two anonymous referees are gratefully acknowledged. The provision of the 2017 Household Labour Force Survey by the Turkish Statistical Institute under the license 27964695-622.03-E.26626 is appreciated.

2 Varol Dur ile Uluslararası Çalışma Örgütü Türkiye Ofisinin Mültecilere Destek Programı çalışanlarına bu makalenin ilk taslağına sağladıkları katkllarından ötürü müteşekkirim. Makaleyi değerlendiren her iki hakemin de destek ve önerileri son derece değerlidir. TÜIK'in 2017 Yll Hanehalkn İsgü̈cü Anketi verileri 27964695622.03-E.26626 no'lu lisans ile kullanılmuştır. 
Anahtar Sözcükler $\quad$ : Türkiye'de Suriyeli Mülteciler, Çalışma Koşulları, Yaşam Koşulları.

\section{Introduction}

The number of revolts that came after the Arab Spring were typically characterised by short-termed demonstrations and/or outbursts of violence in most of the affected countries; all but one: Syria. Since March 2011 until now, none of the multiple belligerents fighting in Syria have been able to regain full control of the country, causing, according to UNHCR, more than 5.68 million $^{3}$ registered refugees of which 3.6 million $^{4}$ have been welcomed by Turkey under the temporary protection regime 5 . For Turkey in particular, this unseen situation has not only brought a humanitarian crisis but has also changed the lives of millions of Turkish people. In this context, the demand for policy responses is pressing and so does the demand for relevant information. This study aims, precisely, at filling an information gap by providing a socio-economic analysis on Syrians' living and working conditions.

Some analyses have already been produced from the point of view of Syrian refugees' impact on the native population. One such example is Ceritoğlu et al. (2015: 12-14) who use the differences-in-differences method to identify the impact of Syrian refugees on the Turkish population inhabiting south-eastern provinces of Turkey. The results of the justmentioned working paper are focused on several labour market-related indicators, finding statistically significant increases in the unemployment rate and reductions in the number of informally employed Turkish workers (by no means fully countered by increases in the number of formal jobs). Moreover, the paper points out that these negative effects on the native population are more strongly felt by -as usual- the most vulnerable sub-groups, young people and women. Even though the findings of my research are generally consistent with the story developed by Ceritoğlu et al. (2015: 16-20), the perfect substitutability between Syrian refugees and Turkish low skilled workers is not that clear. The heavy presence of Syrian refugees in certain sub-occupations ${ }^{6}$, much higher than the ones found among Turkish natives, suggests they may also be performing tasks Turkish people prefer to avoid.

The findings of Ceritoğlu et al. (2015: 14) are not accurate anymore in the southeastern areas of Turkey since Syrian refugees have likely relocated to other provinces ${ }^{7}$

\footnotetext{
According to <https://data2.unhcr.org/en/situations/syria>, 04.04.2019.

Data from the DGMM, updated as of 04.04.2019.

See <https://help.unhcr.org/turkey/information-for-syrians/temporary-protection-in-turkey/>, 04.04.2019 for more information on this regime.

Second digit of ISCO-08 classification.

See an article by the Financial Times at <https://www.ft.com/content/581223c6-c352-11e9-a8e9296 ca66511c9>, 04.04.2019 commenting on the actual count of refugees in Istanbul or the article by Pinedo (2019a) for an estimate of the internal migration patterns of Syrian refugees in Turkey.
} 
(notably Istanbul); however, they are likely applicable in the new host provinces and be able to partly explain the rise in youth unemployment rates in other provinces. In an attempt to expand the results of Ceritoğlu et al. (2015: 16-20), Konun and Tümen (2016: 1-7) and Tümen (2016: 1) also analyse the effects of Syrian refugees on housing rental prices and consumer prices. The first conclusion reached by these authors points at a decrease in the level of prices from goods produced in informal labour-intensive sectors. This is explained by Syrian workers replacing Turkish natives in informal jobs at a cheaper rate, passing the lower labour costs onto the goods' prices. With respect to housing rental prices, they find that it is the relatively expensive houses the ones whose price increased the most, a change that, according to them, suggests a segregation story.

Similar macroeconomic effects are also found by Del Carpio and Wagner (2015: 2024) in an article that also combines microdata from the Turkish Labour Force Survey with macro data on the number of refugees by region. This paper differs from the ones of Ceritoğlu et al. (2015: 12-14), Konun and Tümen (2016: 10-14) and Tümen (2016: 1-2) in that it uses an instrumental variable instead of differences in differences as the identification methodology. In terms of conclusions, Del Carpio and Wagner (2015: 28-29) also find a large displacement of Turkish natives from the informal sector due to the arrival of the refugee population as well as a net displacement of women and the lowly educated away from the labour market.

Other research like the ones published by İçduygu and Millet (2016: 1-6) and İçduygu and Diker (2017: 15-20) look at the Syrian refugee issue from the point of view of integration in the society from a legal and a social standpoint. In particular, these authors highlight the importance of the current legislative challenges faced by Turkey, including the enactment of regulation that prevents refugees from taking on informal jobs or incentives to employers to provide formal jobs to refugees.

Another item related to integration is skill building inasmuch education is still one of the best ways to avoid poverty and segregation. The research carried out by Kaymaz and Kadboy (2016: 3) finds that around 30 per cent of Syrian refugees in migration routes have university degrees. The extent to which that many Syrian refugees have such high qualifications might not be representative of all refugees in Turkey, but it brings to the spotlight the importance of developing a model for recognition of prior learning of refugees. In this regard, my research finds a triple threat in this regard, first, the proportion of highly qualified Syrians has decreased in younger cohorts, second, the few Syrians with tertiary studies tend to work in jobs for which they are overqualified and, at last, their qualifications are not rewarded in the same way Turkish natives' ones are. The need for skill building is also emphasized in, for instance, the study by İçduygu and Diker (2017: 27-28), who argue in favour of skill building programs for refugees as a necessary step toward their integration in the labour market.

In addition to these challenges, the studies prepared by İçduygu and Diker (2016: 1718) and ORSAM (2015: 9) mention an increasing probability that Syrian refugees will become permanent residents of Turkey, in which case the importance of investing in 
education would be even higher. In any case, it is clear that irrespective of whether 3.6 million Syrians become Turkish nationals or not, we are no longer talking about a short-term humanitarian response, but, rather, about a long-term integration problem which demands effective policy responses with respect to education and training.

Despite the existence of research covering future challenges for refugees and some successful attempts at producing studies on the impact of Syrian refugees on the hosting population, little is known about their current circumstances. One of the most remarkable attempts from a sociological point of view is the Syrian Barometer, see Erdoğan (2017: 57), a national-level survey covering 11 provinces and interviewing 1,235 Syrian families, reaching out 7,591 Syrians in total. This survey, in addition to increasing our understanding of Turkish nationals' sentiment in regard to the Syrian population, also provides information on Syrian refugees' educational background which is in line with my findings using the Turkish HLFS microdata. On the negative side, and despite its importance, the study lacks deeper information with regards to Syrians' labour market experiences.

Other studies analysing Syrian refugees' labour market activities are not as ambitious and lack national representativeness. One such example is given by Uçak and Raman (2017: 7), who offer information on Syrian-owned SMEs from Gaziantep and Istanbul. According to these authors, Syrian-owned businesses employ, on average, 9 people while providing signals of dynamism in terms of having plans to keep hiring employees in the near future. Although Syrian entrepreneurship is an area that I cannot study using the Turkish LFS microdata (there are no Syrian employers reported), it is a topic worth researching since the employment and the revenue that these companies are creating may provide some relief to Turkey's labour market.

In summary, Syrian refugees in Turkey are a population that has received plenty of attention from researchers, who, in turn, have studied several aspects of their stay in Turkey. Still, basic labour market indicators such as the unemployment or employment rate, as well as their occupations and labour earnings just to mention a few, are missing altogether and difficult the creation of active labour market programmes as well as necessity assessments. This article tries to overcome this gap in the literature with the help of the methodology developed by Pinedo (2019a: 15-18) that allows for the identification of Syrian refugees in the Turkish Household Labour Force Survey. As a result, I am able to use the full depth of Turkey's LFS to analyse Syrian refugees' living (Section 2) and working (Section 3) conditions. At last, Section 4 of the paper concludes.

\section{Characterization of the Syrian Refugees}

\subsection{Socio-demographics}

The Syrian refugee population is rather unique in several socio-economic aspects. One of these aspects lies on its age distribution, much younger than the population of most countries in the world and on par with many Sub-Saharan African countries. In fact, the average age of the Syrian refugees living in Turkey is 23.0 years old, similar to that of 
Ethiopia and only a few years older than those of Angola (20.6), Zambia (20.7) or the Democratic Republic of Congo (21.7) ${ }^{8}$. These averages are in marked contrast to the average held by, say, Turkish natives, which stands at 33.0 years, in line with other emerging economies ${ }^{9}$.

The young age held by most Syrian refugees directly affects the within age-group balance between Turkish natives and refugees themselves. In fact, even though in 2017 Syrian refugees represented 4.1 per cent of the Turkey-born population, the share among those aged 0-24 was up to 6.3 per cent, see Figure 1(a). Wide-base population pyramids like the one exhibited by Syrian refugees pose short-term and long-term challenges to the wider society; in the present, the high number of Syrian children demand more education services in spite of a relatively limited (since it takes some time to build new schools) number of places. As a result, the number of children per classroom might increase, lowering education quality and creating tensions, specially in the more crowded schools. In addition to the shortterm consequences, a relatively large number of young Syrians is expected to crowd labour markets in regions with a heavy representation of refugees. In this regard, measures directed at skill development for the jobs of the future should begin as soon as possible, together with progressive measures directed at job creation in the affected regions.

\section{Figure: 1}

\section{Syrian Refugee Population, Age Distribution \\ (a) Total Number \\ (b) Population Pyramid}

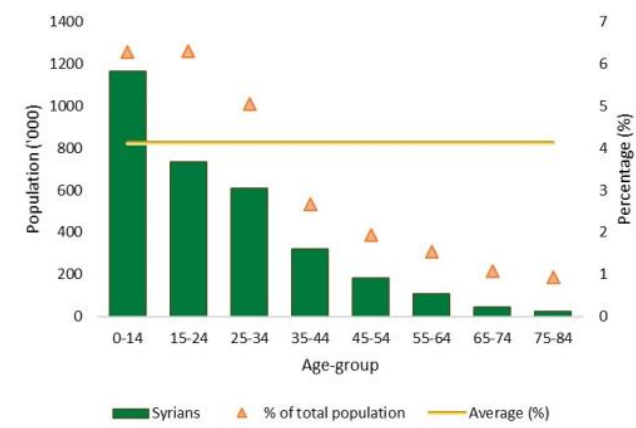

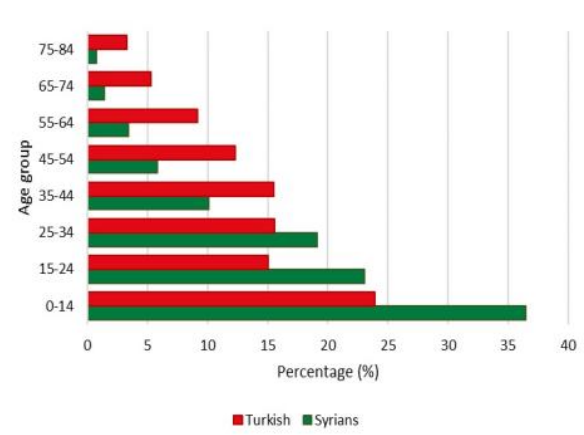

Source: HLFS 2017 and author's own calculations. Notes: The figure shows (a) the total population of Syrian refugees in Turkey together with the percentage of Syrians with respect to the population of Turkish natives by age group and (b) the age group-specific percentage of Syrian refugees in the total population. 
The development of Syrian refugees' skills is not only pressing because of a likely bottleneck in the labour market but also because there is a risk of having a lost generation in terms of access to education. The war disrupted the normal lives of many Syrians and that included their courses of study. An example highlighting this disruption is the 70 per cent of Syrian children not attending an educational institution in Turkey -UNHCR (2014: 52). Similar concerns are reported in an assessment prepared by Bircan and Sunatra (2015: 1011), who also emphasize the economic and social consequences of not providing schooling to Syrian children.

\section{(a) Distribution}

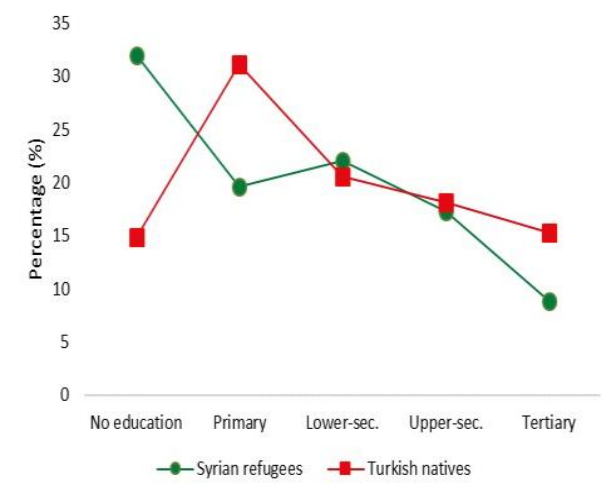

Figure: 2

\section{Educational Attainment of Syrian Refugees}

(b) Percentage with Tertiary Education

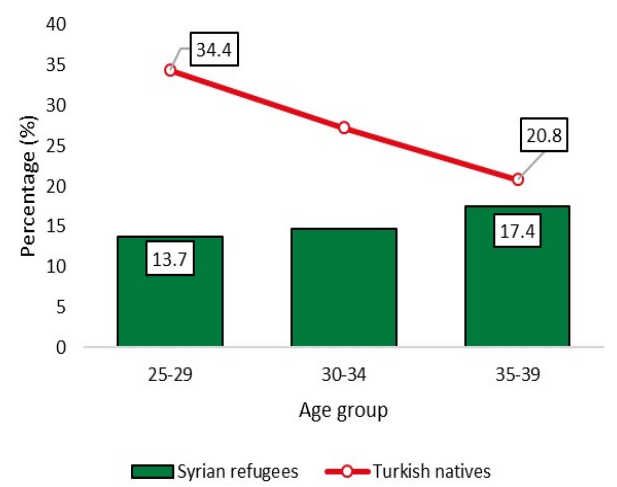

Source: HLFS 2017 and author's own calculations. Notes: The figure reports (a) the nationality-specific percentage of +15 years old Syrians and Turkish natives in each of the 5 educational levels (no education, primary, lowersecondary, upper-secondary and tertiary) and (b) the age group and nationality-specific percentage of Syrians and Turkish natives with tertiary degrees.

Children are not the only ones affected by the limited access to educational resources, though. Many students who should have finished their tertiary studies during the war were not able to do so. For instance, at a time younger cohorts of Turkish natives have been attesting gradual increases in the share of individuals with university degrees, the contrary is found among young Syrians ${ }^{10}$. The different patterns followed by the share of individuals -Turkish and Syrian- with tertiary studies may be best seen in Figure 2(b). In principle it could be argued that the decrease in the rate of university degree holders among Syrians could also be due to a composition effect. This would be the case if, for example, most Syrians aged 25-29 left the country while only the best educated ones among those aged 35-

We do not analyze younger cohorts than those aged 25-29 because they would not have had a chance to finish their studies. 
39 did so. However, the similar number of individuals in these groups tends to favor the disruption theory against the composition effect.

In terms of educational attainment, the main difference between Syrians and their Turkish hosts is found among the least educated ones; while 31.8 per cent of Syrians (aged 15 or older) did not complete primary education only 14.9 per cent of Turkish natives left school at such an early stage. This difference in primary school dropouts in further translated in higher percentages of Turkish people with primary education but not among those with secondary or tertiary education. This distribution might be due to the Syrian population being relatively young in comparison with the Turkish one under analysis. Anyhow, the information presented in Figure 2 suggests the existence of some highly capable Syrians that might not be realizing their full potential, something that is not only negative for them but also for the Turkish economy.

\subsection{Labour Force Status}

Young Syrian refugees saw their advanced education disrupted and chances are it will continue being so in the foreseeable future -at least until current kids make it to the university. For men, low schooling rates among refugees are reflected on a very strong labour market attachment, which is, in turn, translated into an employment rate of 66.1 per cent for 15-year-old boys. Such figure presents an unique situation when compared with other labour markets in the world. Indeed, not even the rural populations of developing African's countries reach this proportion nowadays. Three factors might be behind the high employment rate found among young Syrians: First, many Syrian boys may find themselves idle since they do not attend school. Then, there is a pressing need for income arising from the fact that most Syrians work informally earning less than the minimum wage (see Section 3 where this point is further developed). Last, but by no means the least important reason, is a cultural background where men are expected to work away from home while women are expected to do so at home.

The case of Syrian women is diametrically opposed to that of men; only 11.2 per cent of those aged 15-65 work compared with the 71.0 per cent of men who do so. To some extent, this detachment from the labour market seems to have increased their schooling rate with respect to that of men, although it is still far away from the one held by Turkish women - see Figure 4(a) and (b). The small percentage of working women among Syrians is not uncommon across MENA region countries; Morocco (11.4 per cent, 2010), Iraq (9.8 per cent, 2012), Tunisia (20.8 per cent, 2014) or Jordan (13.8 per cent, 2016) are examples of countries with a closer cultural background to Syria also showing low female employment rates.

Even though cultural factors are undeniably behind the observed low female employment rates, current working conditions may not be very helpful either. On the one hand, informal work arrangements are known to deter women from keeping jobs in the longrun and, on the other hand, the long working hours typically worked by Syrian refugees give women a hard time achieving an optimal work-life balance. In addition, the high proportion 
of children in the refugee population is likely to be an added burden in Syrian women's attempts to join the labour force.

\section{Figure: 3}

(a) Syrian Refugees

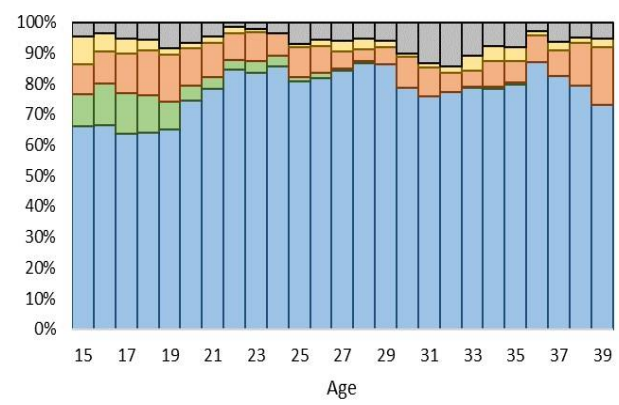

口Employed aln education aUnemployed aHousekeeper aOther

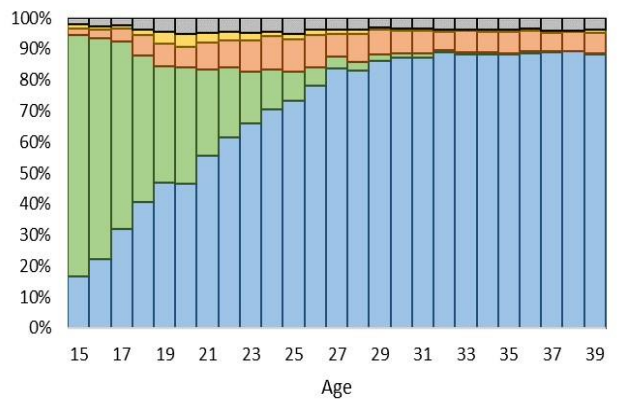

口Employed $\square$ In education $\square$ Unemployed $\square$ Housekeeper aOther

Source: HLFS 2017 and author's own calculations. Notes: The figure shows the age-specific percentage of men in each of the labour force statuses (employment, education, unemployment, housekeeping and other) among (a) Syrian refugees and (b) Turkish nationals. Employment is measured with the ILO definition and includes students who are also working. Unemployment is defined broadly, including discouraged job-seekers.

Figure: 4

Labour Force Status by Age, Women

\section{(a) Syrian Refugees}

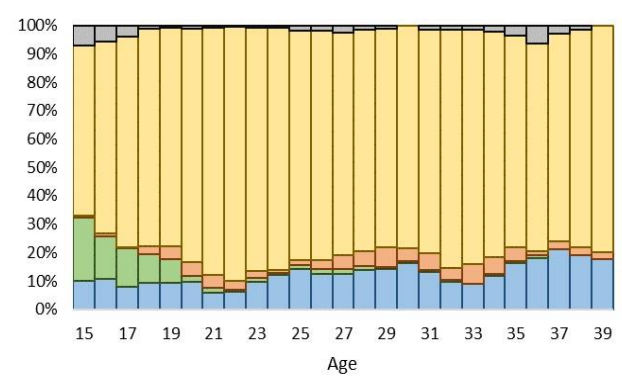

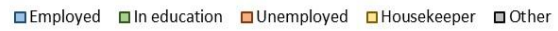

(b) Turkish Natives

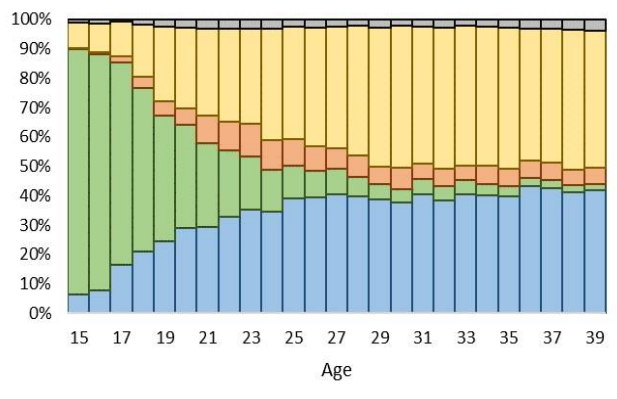

$\square$ Employed $\square$ In education $\square$ Unemployed $\square$ Housekeeper $\quad$ OOther

Source: HLFS 2017 and author's own calculations. Notes: The figure shows the age-specific percentage of women in each of the labour force statuses (employment, education, unemployment, housekeeping and other) among (a) Syrian refugees and (b) Turkish nationals. Employment is measured with the ILO definition and includes students who are also working. Unemployment is defined broadly, including discouraged job-seekers.

An interesting aspect of Syrians' labour market experience is the similar unemployment rates adults (those aged 30-65), 13.3 per cent, and young people (ages 15 to 
29), 13.0 per cent, share. This situation is not only rare in Turkey, where young people have historically endured much higher unemployment rates than adults (18.0 per cent vs. 8.1 in 2017) but also in most other countries of the world. The reason behind this oddity might be found in the fact that both, young people and adults, start afresh in the Turkish labour market, i.e. with no recognition of prior-learning and in many cases no professional networks to rely on. In a sense, the Syrian experience in Turkey may be regarded as a natural experiment that tests whether adults have lower unemployment rates because they are more productive or just because they have spent more time in the labour market than young people.

Table: 1

Key Labour Market Statistics, by Sex and Nationality

\begin{tabular}{|c|c|c|c|c|}
\hline & & \multicolumn{3}{|c|}{ Rate (\%) } \\
\hline \multicolumn{2}{|c|}{ Group } & Participation & Unemployment & NEET \\
\hline \multirow{3}{*}{ 蛋 } & Men & 81.0 & 12.3 & 19.6 \\
\hline & Women & 13.7 & 18.2 & 82.2 \\
\hline & All & 47.5 & 13.1 & 50.1 \\
\hline \multirow{3}{*}{ 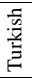 } & Men & 77.9 & 9.6 & 12.6 \\
\hline & Women & 37.6 & 14.3 & 30.7 \\
\hline & All & 57.8 & 11.1 & 21.5 \\
\hline
\end{tabular}

Source: HLFS 2017 and author's own calculations. Notes: The table shows sex and nationality-specific (a) labour force participation rate, (b) unemployment rate and (c) NEET rate for Syrian and Turkish men and women. The NEET rate refers to the percentage of 15-24 year old people who are neither in employment nor in education or training. Labour force participation rates and unemployment rates are defined for those aged 15-65.

In addition, it seems that Syrian and Turkish women have higher unemployment rates than the men of their respective nationality. A plausible explanation could go along the lines of women having less chances than men have in the labour market. Other reasons should not be discarded, though. For instance, the fact that most men work may lower women's pressure to find a job. In addition, women being in charge of household duties may decrease the number of jobs they can to apply to.

Low female employment rates and the small number of young women in education result in one of the highest female NEET rates in the world, almost doubling those held by, for example, India (46.6 per cent, 2012) or Bangladesh (43.6 per cent, 2016), to name two of the countries with some of the highest female NEET rates. In contrast, the male NEET rate held by Syrian refugees (see Table 1) is much lower than that of Syrian women although this is the result of men being engaged in employment from an early age, which is not positive for their career development.

\subsection{Labour Market Transitions and Employee Turnover}

Syrian refugees are likely to have rather unstable labour market experiences, jumping from one job to another. However, they would also be expected to learn their way around the Turkish labour market as time goes by. This is, in fact, what the data reveals; as of 2017, 
year-to-year transitions ${ }^{11}$ have improved for refugees in comparison with 2015. For instance, the share of those who were unemployed in 2016 and had found a job in 2017 is higher among Syrians than among natives. Likewise, the share of those employed as salaried workers in 2016 who continued being so in 2017 is similar for both of the mentioned groups while it used to be lower for Syrians.

\section{Figure: 5 \\ Current (2017) Labour Force Status of 2016 Employees}

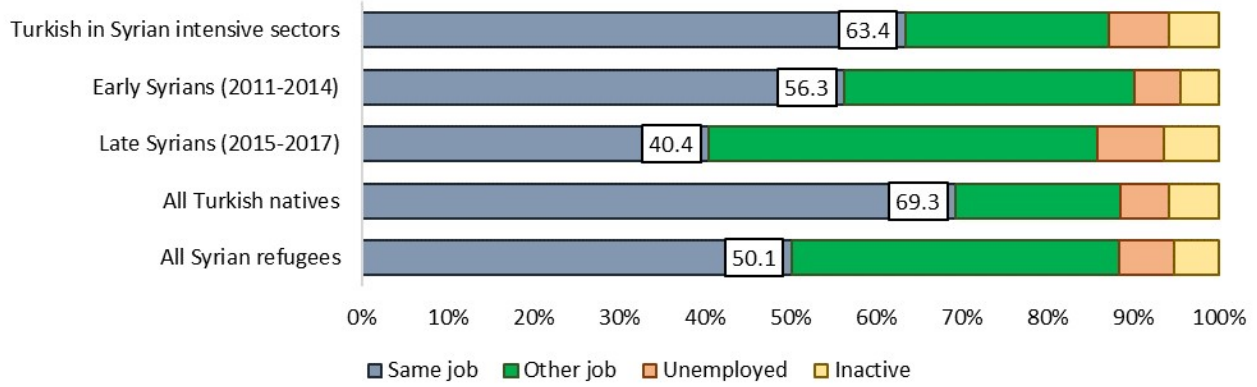

Source: HLFS and author's own calculations. Notes: The figure shows 2016 employees' labour force statuses after one year for 15-65 year-old individuals. The percentages are group-specific. 'Turkish in Syrian intensive sectors' refer to employees in construction, trade and manufacturing. The terms 'early' and 'late' refer to the date of arrival to Turkey; early means 2011-2014 and late 2015-2017.

Shorter unemployment spells are positive in the sense of guaranteeing an steady flow of income but they also signal Syrians would take on any job regardless of its conditions. This could, at least partially, explain why half of the refugees had changed jobs in the last year, compared to 30.7 per cent of Turkish natives (see Figure 5, bottom rows). Higher employee turnover could, in principle, be a deterrent for employers to request the necessary work permits. However, this behavior could be openly discriminatory; in reality, Syrian refugees' turnover rates are approaching fast those of comparable Turkish workers. For instance, among employees in trade, construction and manufacturing, the turnover rate of Syrians arrived between 2011 and 2014 is only seven percentage points higher than among Turkish.

A similar conclusion arises when comparing the number of years (permanency) of refugees in their jobs. As things stand in 2017, Syrian refugees have been serving their employers 4.4 years less than Turkish natives. It is when we take into account the fact that they have spent less years in Turkey than the average Turkish person, the type of sectors where they work on and the nature of the contract offered by the employer, that the 
difference in permanency goes down to half a year. It should also be noted that temporary contracts, which are often found in agriculture and construction, are generally accepted (91.3 per cent) because the person could not find a longer-termed work relationship, not because it was their preferred choice. To sum up, Syrians seem to prefer long-term over short-term contracts and their permanency and turnover rate do not differ much from the one held by comparable Turkish workers.

\subsection{Working Children}

One of the drawbacks of the HLFS has to do with the labour and education modules not targeting individuals younger than 15 years old. As a result, critical information on school enrollment and on the number of working children is missing. Still, the small percentage of 15 years old Syrians in education signals that a large share of Syrian children might find themselves out of school. For example, I find that only 29.4 per cent of 15 -yearold Syrian girls attend school, compared to the 86.8 per cent attested among Turkish girls of the same age. An even bigger gap exists between 15-year-old Syrian and Turkish boys, with, respectively, 12.9 and 88.4 per cent attending school.

\section{Figure: 6}

\section{Underage Workers Among Syrian Refugees in Turkey (Extrapolation)}

\section{(a) Number of Workers Aged 5-14}

(b) Employment Rate
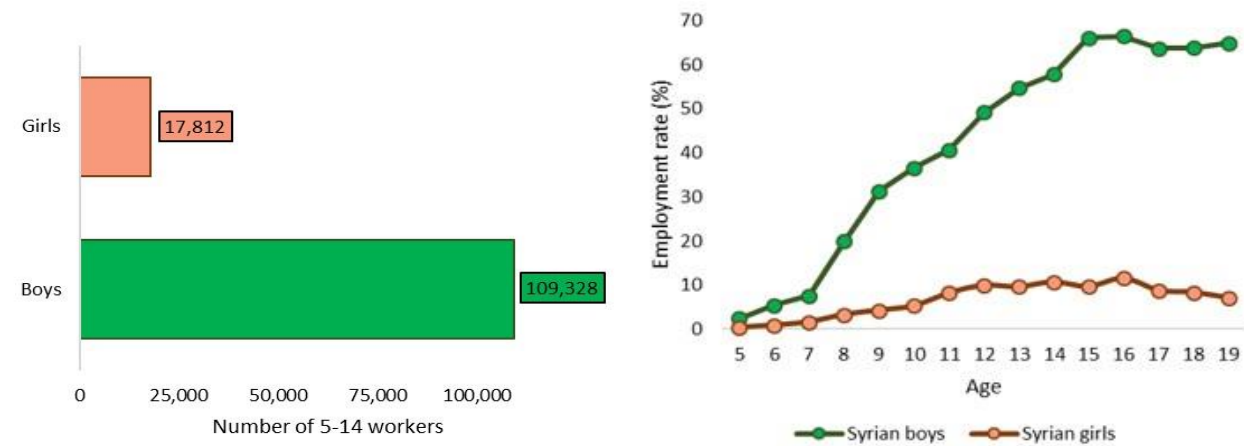

Source: Turkey HLFS 2017, Zambia LFS 2008 and author's own calculations. Notes: The figure shows (a) the number of 5-14 Syrian children working in Turkey separately for men and women and (b) the age-specific employment rate for men and women. The data referring to the employment rates of those aged 5-14 has been extrapolated with the help of the 2008 LFS of Zambia (urban areas).

Same way Syrian boys are not expected to massively attend school, they are also suspected to work in high numbers, especially after taking into account the high employment rate held by those aged 15 (66.1 per cent). Figure 6(b) shows an attempt to recover the missing data on children employment rates by extrapolating backwards the employment rates held by those aged 15 . This exercise is done with the help of children employment rates 
from urban -because this is the area where most Syrians live- ${ }^{12}$ areas of Zambia. I bring the proportion of children working between 5 and 15 while forcing the data to match the employment rate of Syrians at age 15. In other words, I bring the shape, not the height of the bar -which is given by actual data on Syrians- from Zambia. The exercise is done separately for girls and boys.

Why Zambian data? Several data sources are considered and rejected. An obvious candidate would be former child labour surveys carried out in Turkey, but the socioeconomic conditions of Syrian refugees have little in common with those of native Turkish and the estimates would likely be biased downwards. A second possibility for the extrapolation would have been Jordan's LFS where a large number of Syrian refugees may be identified. On the negative side, this survey does not ask questions from the labour module to anyone below the age of $15^{13}$. Other candidates for the extrapolation are migrant populations elsewhere in the world. Unfortunately, available data sources of south-north migrants do not include children as part of their labour modules. South-south migration data is not ideal either; for example, in Ethiopia the few observations available in the data prevent us from accurately calculating employment rates that may be extrapolated.

In the end, I discard using migrants' data and instead I rely on working children data from natives. As a result of this choice three data sources that fulfill the minimum criteria for a meaningful extrapolation are identified: Bangladesh, Tanzania and Zambia, all of which asked children aged 5-14 questions from the labour module. These three cases are chosen because 1) there is a population at risk of poverty, meaning children might need to bring income from an early age and 2) informal work arrangements are prevailing among young people. Of these candidates, Bangladesh is dropped because there is a sharp jump ${ }^{14}$ in the share of formal workers at 15 years old -because they reach the legal age to work. At last, the choice between Tanzania and Zambia is solved in favor of the latter just because it has a bigger sample size and, thus, more accurate results.

The extrapolation results are shown in Figure 6, with the total number of Syrian working children estimated in 127,140 -see part (a)- of which 109,328 are boys. In addition, estimated sex and age-specific employment shares are shown in Figure 6(b) for girls and boys aged $5-14^{15}$. These estimates are speculative and are shown for informative purposes

12 HLFS 2017 and author's own calculations. Note that since 2014 rural/urban distinctions are not present in Turkey's HLFS. Instead I created a rural/urban indicator in the HLFS using a variable that asks people changing provinces whether they were living in rural or urban areas. The indicator is then imputed for the remaining individuals at the family level.

13 And even if it has asked those questions to children the fact that the language in education is Arabic would change school attendance rates and the share of working children, losing, as a result, any resemblance with respect to the situation in Turkey.

14 From 0 to 10 per cent, something not likely to be observed among Syrian refugees.

15 Note that the employment shares for those aged 15-19 are based on real data from the HLFS 2017. 
exclusively, however, the severity and urgency of the situation if these figures were close to be true demand more information on the topic. Reasons behind this pressing need for information are first of all, humanitarian; these children should be attending school so as to get the best possible start in life. Moreover, the completion of compulsory education opens the door to university degrees and a higher number of future opportunities in the labour market. Apart from having an accurate estimate of how many Syrian children are working, gathering information on these kids' family situations and the sector their employers belong to would also help policy makers in the creation of measures aimed at lowering both, the demand and the supply of child labour.

\section{Type of Employment and Working Conditions}

It is estimated that 940,921 Syrians work in Turkey as of $2017^{16}$, most of them men and some working from an early age (Figures 3 and 4). Among these, 862,039 (91.6 per cent) do so informally, occupying low-skilled positions in sectors where productivity is relatively low. These facts raise questions with regards to the quality of the jobs held by Syrians and the kind of industries that provide them. This section analyses, to the extent possible given the data limitations, where and how Syrian refugees work, with an emphasis on wages and hours worked. It should be noted that no information is available for working children in the HLFS ${ }^{17}$. This section, thus, covers the 813,781 Syrian workers who are 15 years old or older.

Table: 2

Number of Syrian Refugees by Economic Activity

\begin{tabular}{|c|c|c|c|}
\hline Activity & Total number of Syrians & Share among Syrians & Within sector share \\
\hline Agriculture & 63,110 & 7.8 & 1.2 \\
\hline Manufacturing & 392,350 & 48.2 & 7.4 \\
\hline of which TCLF & $(252,888)$ & $(64.5)$ & $(16.1)$ \\
\hline of which others & $(139,462)$ & $(35.5)$ & $(3.7)$ \\
\hline Construction & 107,389 & 13.2 & 5.2 \\
\hline Transport and comm. & 11,492 & 1.4 & 0.8 \\
\hline Trade and hospitality & 144,273 & 17.7 & 2.6 \\
\hline of which retail & $(51,572)$ & $(35.7)$ & $(2.0)$ \\
\hline of which food & $(43,363)$ & $(30.1)$ & $(3.5)$ \\
\hline of which others & $(49,338)$ & $(34.2)$ & $(3.0)$ \\
\hline Business activities & 12,843 & 1.6 & 0.5 \\
\hline Education & 22,258 & 2.7 & 1.4 \\
\hline Health & 8,990 & 1.1 & 0.8 \\
\hline Other services & 51,076 & 6.3 & 5.0 \\
\hline Total (1)-(2)/Average (3) & 813,781 & 100.0 & 2.9 \\
\hline
\end{tabular}

Source: HLFS 2017 and author's own calculations. Notes: The table shows (i) the number of Syrian refugees working in each economic activity, (ii) the nationality-specific share of Syrian workers in each economic activity and (iii) the sector-specific share of Syrian workers. TCLF refers to textile, clothing, leather and footwear, ISIC rev.4 codes 13,14 and 15 .

16 Including the estimates on working children from Figure 6(a).

17 Clearly, those aged 5-14 work informally by definition, but little else is known about them. 


\subsection{Employment Structure}

The economic activities conducted and occupations held by Syrian refugees are determined by their informal working arrangements. As such, sectors like trade, construction and manufacturing, which have historically showcased high informality rates, became the main receivers of Syrian labour. In total, these three sectors account for 79.1 per cent of Syrian workers (Table 1); however, one of these sectors stands out in terms of employment: the textile, clothing, leather and footwear industries (TCLF) provide jobs to almost one in every three Syrians. The reasons behind this sector's attachment to Syrian labour are twofold. On the one hand, garment is a sector that has historically been characterised by high informality rates in the Turkish labour market. On the other hand, extreme competition on the international level presses garment employers to hire cheaper workers ${ }^{18}$. In addition to these activities, a relatively high share of Syrians is working in a black box called 'other services'. In practice, a combined analysis of ISCO and ISIC codes at the 2 digit level allows us to shed some light, finding that these services refer -mostly- to repair of personal goods and clothing activities (the latter are garment workers occupationally speaking but not in terms of economic activity) vehicles and domestic cleaners as well as possibly some waste pickers/scrap collectors.

There are cases where the concentration of Syrians working in particular activities has produced an impact on the national level despite the fact that Syrians only represent 2.9 per cent of all Turkish workers. Some candidates to witness this impact include the TCLF industries, where Syrians represent 16.1 per cent of the Turkish workers and the construction sector, with 5.2 per cent. The impact includes profitability boosts due to the low salaries and the informal nature of the workers but also the crowding out of national workers -especially those with few years of schooling- who might not find an informal job with the same ease as before.

In addition to enhancing the survivability of certain companies, Syrian refugees are also modifying nation-wide informality rates. This is especially so in the garment sector (Figure 7) which currently showcases an informality rate of 38.5 per cent with Syrian refugees and 30.4 without them ${ }^{19}$. Higher informality rates may also be seen in the construction sector, as well as in food and beverage service activities. In the last two cases, though, the difference between the informality rates attained with and without Syrian refugees is more modest. The effect of Syrian refugees on the country level is smaller but still significant. The share of informal workers (including those self-employed) goes from 34.4 per cent without Syrians to 36.0 per cent with them. The difference when only

18 It is estimated -Pinedo Caro (2019b)- that textile and garment companies save around 2.8 billion Turkish Lira of 2017 per year by using informal Syrian labour.

19 The informality rate without Syrian refugees is probably lower than it would have been if Syrians had never come to Turkey. This is because Syrians may have crowded out some of the Turkish informal employees that used to work in the sector. 
employees are taken into account is slightly larger, going from 17.4 per cent to 20.1 per cent, but in either case, the strong trend towards formal work arrangements that Turkey has witnessed in recent times has been partially reversed.

\section{Figure: 7}

\section{Share of Informal Workers with and without Syrian Refugees, Selected Sectors}

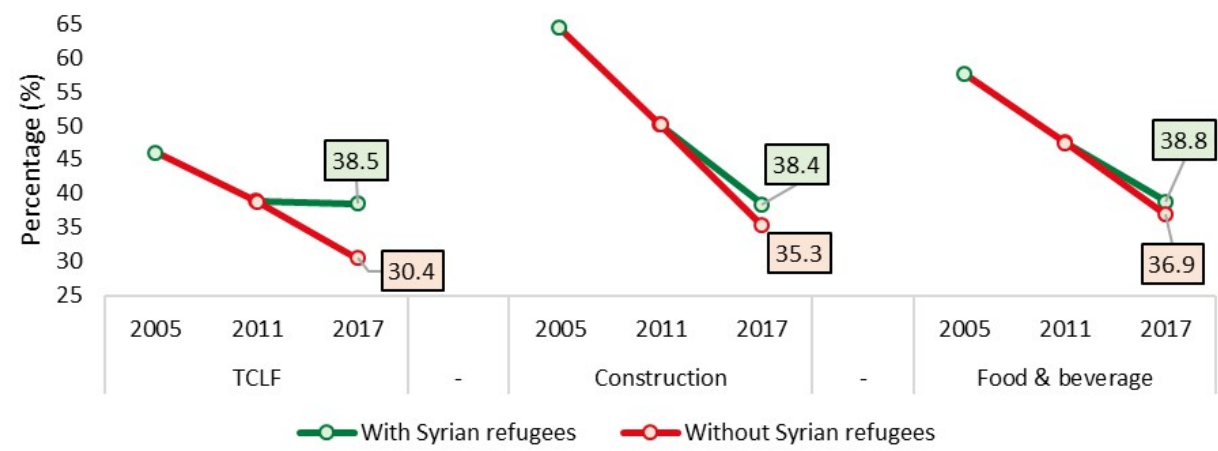

Source: HLFS and author's own calculations. Notes: The figure shows the share of informal workers in Turkey in three economic activities for the years 2005, 2011 and 2017. The 2017 figures are estimated with and without the presence of Syrian refugees and use the weight adjustments proposed in Appendix C. 'TCLF' refers to the textile, garment, leather and footwear industries.

A high percentage of Syrians may be found in low and semi-skilled occupations. This is partly due to their low number of years in school but also the informal nature of the jobs held and the type of sector where they are employed. Indeed, the occupations held may be traced back to the economic activities they work for. For instance, among labourers in manufacturing and construction (ISCO-08, group 93), more than a third work in the construction sector while half of them do so in the manufacturing industry. Likewise, the majority (89.1 per cent) of stationary plant and machine operators are employed in the TCLF industries. Aside from the traceability between economic activities and occupations, what stands out of the occupational distribution is that 32.0 per cent of Syrians work in low-skilled occupations, while 60.9 per cent do so in semi-skilled ones. Put differently, only 7.2 per cent of them work in high-skilled occupations, in comparison to 21.0 per cent of Turkish natives.

In principle, the occupations held by Syrian refugees (most of whom are informally employed) and informal Turkish workers ${ }^{20}$ would be expected to be of similar nature, putting Syrians forward as direct competitors of informal Turkish workers for the same jobs. However, a closer look at the last two columns of Table 3, which shows nationality-specific employment shares by occupation, reveals that this is not exactly the case. Syrian refugees 
have a much higher chance to be employed as manufacturing laborers, machine operators and garment workers (groups 75, 81 and 93) than informally employed natives. In other words, Syrians might be, to some extent, complementing -instead of substituting- Turkish labour occupying jobs natives might not be willing to perform.

Even though in purely economic terms, Turkey might momentarily benefit from having Syrians with skills that mostly complement those of natives, it is unclear whether the country would be better off in the long-term. On the one hand, keeping a large share of Syrians in low-skilled occupations hinders their chances for a quick integration while maintaining a drain on many social services. The slow integration might also cluster Syrians in poor neighbourhoods, potentially generating social conflict. On the other hand, cheap labour might foster what would otherwise constitute unprofitable economic activities, taking valuable resources from long-term sustainable, more productive sectors.

Table: 3

\section{Number of Syrian Refugees by Occupation}

\begin{tabular}{|l|c|c|c|}
\hline \multicolumn{1}{|c|}{ Occupation (ISCO code) } & \multicolumn{2}{c|}{ Syrian refugees } & \multicolumn{1}{c|}{ Shformal Turkish workers } \\
\hline \multicolumn{1}{|c|}{ Total } & Share & \\
\hline Labourers in manufac. and construc. (93) & 137,210 & 16.9 & \\
\hline Stationary plant and machine opera. (81) & 131,305 & 16.1 & \\
\hline Woodworking and garment workers (75) & 105,123 & 12.9 & \\
\hline Sales workers (52) & 61,194 & 7.5 & 15.9 \\
\hline Building and related trades workers (71) & 57,440 & 7.1 & \\
\hline Agricultural labourers (92) & 56,429 & 6.9 & \\
\hline Metal, machinery workers (72) & 38,741 & 4.8 & \\
\hline Personal services (51) & 35,281 & 4.3 & \\
\hline Cleaners, helpers (91) & 35,000 & 4.3 & \\
\hline Other occupations & 156,058 & 19.2 & \\
\hline \multicolumn{1}{|c|}{ Total } & 813,781 & 100.0 & 4.3 \\
\hline
\end{tabular}

Source: HLFS 2017 and author's own calculations. Notes: The table shows (i) the number of Syrian refugees by occupation, (ii) the population-specific share of Syrian refugees and informal Turkish workers in each occupation. Subsistence agricultural workers are excluded from the Turkish group for better comparability. Occupations are measured using ISCO-08 codes.

Another negative side of Syrians being clustered in low-skilled, informal jobs has to do with the existence of overqualified workers. It is estimated that 84,479 Syrians -roughly 10 per cent of all Syrian workers- work with tertiary degrees. However, as it may be seen in Figure 8, only 28.9 per cent managed to find a job in the professional category. By digging into the specific occupations held by Syrian workers in the professional category, it is possible to find that half of them work as teachers without a work permit, narrowing further down the range of available professions for this group. A plausible reason for their lack of access to high-skilled jobs could be related to the existence of a language barrier. However, this should not be interpreted as that teaching Turkish to random Syrians would improve their labour market experiences in the short-run. Syrians are relatively clustered in a few provinces, and chances are that their customers/co-workers are Syrian, too. High-skilled Syrian refugees, though, might benefit greatly -themselves and their hosting country- from more integration, including learning Turkish.

In addition to a different language, problems in validating foreign degrees and acknowledgment of prior learning are likely to lower the value of Syrians' capacities, 
particularly in highly regulated professions where signals matter as much -if not more- than actual human capital. Together with the two mentioned reasons, the fact that high-skilled jobs are usually provided under formal work arrangements poses a triple threat to welleducated Syrians in their quest to use their abilities.

Figure: 8

\section{Occupations of Tertiary Degree Holders, by Nationality}

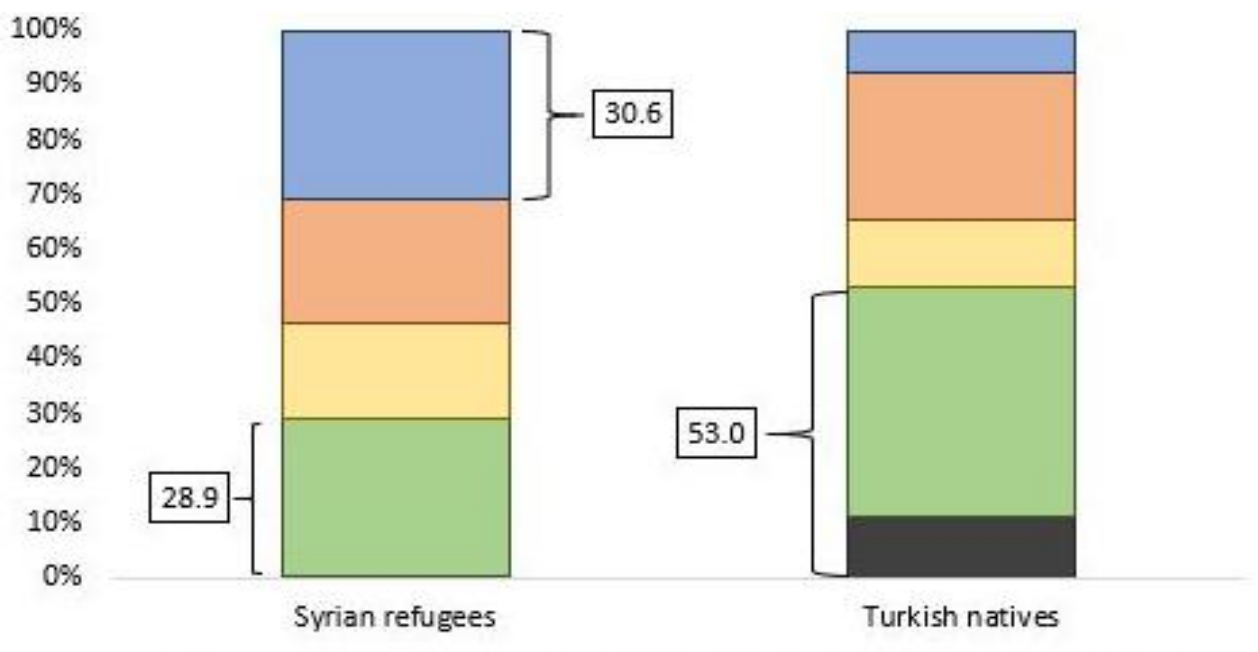

Managerial $\square$ Professional $\square$ Technicians $\square$ Clerical/sales $\square$ Bluecollar

Source: 2017 HLFS and author's own calculations. Notes: The figure shows the education and nationality-specific occupational distribution for Syrian refugee and Turkish native workers with tertiary education. Occupations measured with ISCO-08 codes.

Although high-skilled Syrians might be among the ones who lost the most in terms of foregone earnings due to their lack of work permits, informal work arrangements are pervasive across Syrian refugees with more than 9 in 10 working without being registered at the social security institution. Generally, employees hired informally tend to work in small businesses. This is for two reasons; firstly, because this practice is unlawful, and it is easier to conceal the activity if the premises are not visible. Secondly, because these businesses tend to be less profitable than bigger companies, and thus, might need to rely on a cheaper workforce. On the international level, examples of this behaviour are easy to find ${ }^{21}$. In Mexico 81.6 per cent of informal employees work in businesses with less than 10 employees

21 The examples provided rely on microdata from the ENOE 2016 I for Mexico, LFS 2016 for Egypt and Employment-Unemployment NSSO 68th round for India as well as the author's own calculations. The data from all three countries have been harmonized and are part of the LFM v2.0. 
while in India and in Egypt these percentages are, respectively, 86.7 and 88.4 per cent. A similar share of informal employees working in micro-enterprises is also found in Turkey for natives, 78.5 per cent, with almost half of them working in hard to spot (non-regular) places such as irregular/mobile premises or at home (Figure 9a).

Surprisingly, the empirical regularity regarding company sizes for informal employees is broken for Syrian refugees. As seen in Figure 9b, 43.8 per cent work informally in businesses of more than 10 people. Moreover, it is not like these Syrians are working in companies just marginally bigger; 32.0 per cent work in companies with more than 20 employees, something rare to witness elsewhere in the world of work. On top of the high share of informal employees working outside of micro-businesses, those working in companies with less than 10 employees also showcase a higher tendency to do so in regular premises which are arguably easier to spot by the labour inspection.

To sum up, Syrian refugees' employment structure is uncommon in terms of the combination of characteristics -informal employment in relatively large companies, high prevalence of the manufacturing sector and definitely only representative of Syrians in Turkey. For instance, in Jordan, only 20.6 per cent (48.2 per cent in Turkey) of Syrians are employed in the manufacturing sector, while 36.8 per cent work in the construction sector, and 29.8 in trade and hospitality. The aforementioned characteristics are not necessarily negative, though, and might play in favour of Syrian refugees' future labour market experiences. The relatively high visibility of the businesses where Syrians work could, in principle, be used by the labour inspection of Turkey to optimize its efforts in reducing informality. Moreover, the productivity of the manufacturing industries is higher than that of the trade and hospitality sector, increasing the viability of the formalization of Syrian refugees in their current posts. Clearly, the aforementioned remarks would do little good if Syrians are not eligible to receive a work permit.

\section{Figure 9: Firm Size Distribution and Type of Microbusinesses, Informal Employees}

\section{(a) Turkish Natives}

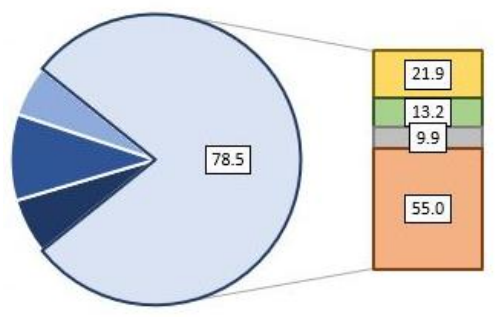

(b) Syrian Refugees
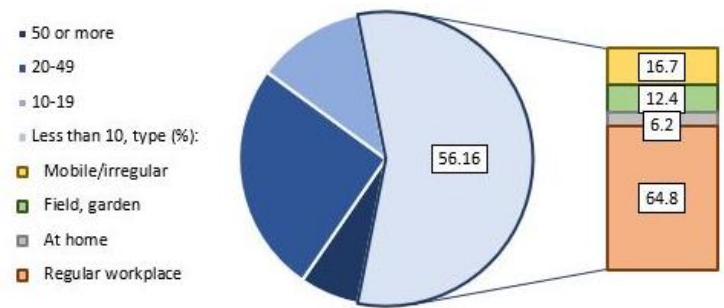

Source: 2017 HLFS and author's own calculations. Notes: The figure shows (i) the nationality-specific distribution of company sizes for Syrian refugee and Turkish informal employees (in blue) and (ii) the nationality and company size-specific share of workplace types for companies with less than 10 employees. 


\subsection{Working Conditions}

High informality rates and jobs clustered in some of the sectors where longer hours ${ }^{22}$ are worked in Turkey are likely to shoot up the hours worked by Syrian refugees beyond legal limits. Indeed, Syrian refugees work, on an average week, for 52.3 hours, almost five and four hours more than, respectively, formal and informal native employees. Additionally, more than half (53.7 per cent) of Syrian employees work more than 50 hours a week, and 34.7 per cent work 60 or more hours.

Figure 10: Employees Average Weekly Hours Worked, by Nationality
(a) Syrian Refugees
(b) Turkish Natives
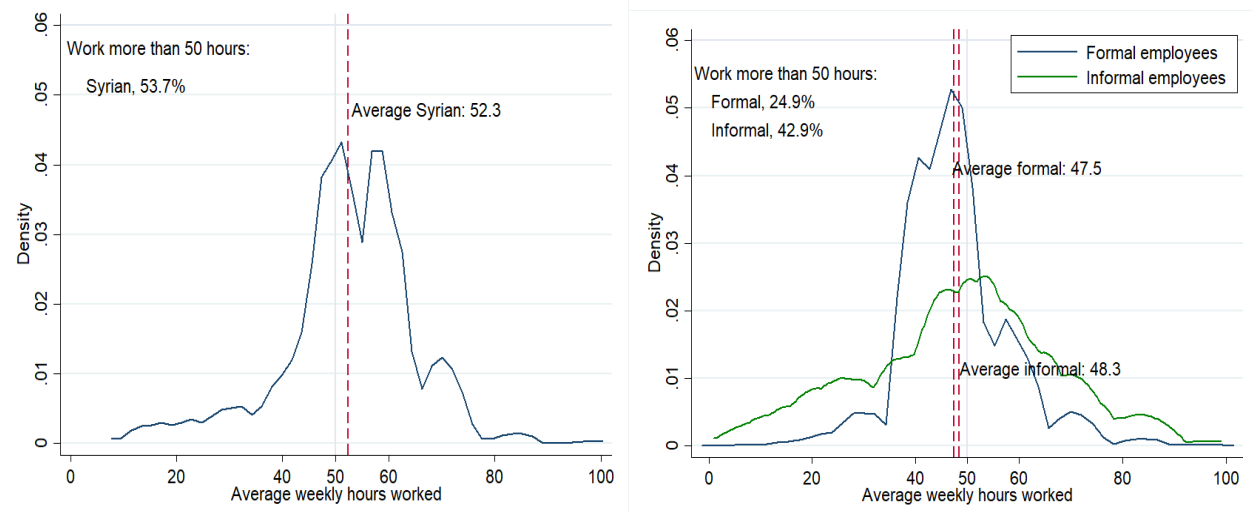

Source: HLFS 2017 and author's own calculations. Notes: The figure shows the distribution (probability density function) of average weekly hours worked by (a) Syrian employees, (b) Turkish informal employees and (c) Turkish formal employees using Kernel density estimation. The height of graph corresponds to the frequency of employees with a given number of hours worked.

The complete distribution of average weekly hours is provided in Figure 10(a) for Syrian employees and in Figure 10(b) for, separately, Turkish formal and informal employees. At first sight, the distribution of hours worked by Syrians resembles neither of the natives' distributions. However, the devil is in the detail, and a closer look reveals things are not really that different. For instance, weekly hours worked by formal natives go up by 2.1 when removing the public sector -represented in Figure 10(b) by the peak at 40 hours. That is, without public employment (that belongs exclusively to formal native employees) both, Syrians and Turks' distributions share a peak at 48 hours, the most common arrangement in Turkey. Still, the distribution of hours worked by Syrians is 'shifted' to the right, with a second peak at 60 hours which is characteristic of the informal economy. The 
distribution of hours worked by informal natives does not seem to fit the Syrian one; the former has a much 'heavier' left tail (individuals who work part-time) than that of Syrian refugees. However, if we only consider full-time informal employees, Syrians (55.0 hours) and informal native employees (55.8 hours) look very much like each other. In summary, it could be stated that the Syrian refugee distribution of hours worked is similar to full-time informal Turkish employees (right-hand side of the distribution) while part-time arrangements are almost non-existent.

A salient issue of the weekly distribution of hours has to do with the low prevalence of part-time arrangements among Syrians and natives. Despite an increase in this mode of work from 10.1 per cent back in 2005 to 14.4 in 2017 among 15-65 female employees, this still falls short in comparison to some European countries like France (30.5 per cent, 2016) or the United Kingdom (44.8 per cent, 2016). This, in turn, might still constitute a barrier of entry to the labour market for women who also carry out duties at home.

Another reason that might be driving Syrian women away from the labour market is the lower wages earned in comparison to men. The unadjusted monthly gender wage gap for Syrian refugees stands at 23.4 per cent while the hourly counterpart is 9.4 per cent. These are, in both cases, higher than the gender wage gaps of Turkish citizens ${ }^{23}$. Women are not the only disfavoured group among Syrian refugees and young people (15-29 years old) also earn 18.2 per cent less than adults per month and 21.6 per cent less per hour worked.

Irrespective of the group we put the focus on, Syrian refugees' jobs are characterised by low earnings, where the average take-home salary is 1,302. Minimum wage compliance provides a darker picture when assessed from an hourly point of view. Syrians tend to work more than the 45 hours required to earn a full-time salary, and as a result, 3 out of 4 Syrian employees earn less than the minimum wage per hour. The percentage of Syrians earning below the minimum wage is slightly lower in Istanbul, where refugees enjoy higher wages than those in other regions. However, this difference is likely due to the higher living cost displayed by the largest city of Turkey and not to the generosity of employers. Perhaps surprisingly, in the light of the gender wage differential is the fact that a higher share of men earns below the hourly minimum wage, 76.8 per cent in comparison to 68.7 . This result is driven by the shape of the genders' wage distributions; low female earners earn very little but there is a higher percentage of them earning above the minimum wage than those among men.

23 This does not necessarily mean Syrian women are more discriminated against than Turkish women. Their jobs are very different. For example, Syrian women do not have access to public employment - a major earnings boost for Turkish women-and tend to be employed in low-skilled professions where the gender wage gap is the highest. 
Table: 4

\section{Syrian Employees' Net Earnings}

\begin{tabular}{|c|c|c|c|c|c|c|c|}
\hline & \multicolumn{9}{|c|}{ Syrian employees } \\
\hline Statistics & All & Male & Female & Istanbul & Other areas & Young & Adult \\
\hline Average monthly wage & 1,302 & 1,337 & 1,083 & 1,460 & 1,177 & 1,216 & 1,438 \\
\hline Average hourly wage & 6.21 & 6.29 & 5.75 & 6.81 & 5.74 & 5.73 & 6.97 \\
\hline
\end{tabular}

Source: HLFS 2017 and author's own calculations. Notes: The table shows average hourly and monthly net wages of Syrian refugees measured in nominal 2017 TRY by sex, age-group and Istanbul/rest of the country. Young refers to those aged 15-29 and adult to those aged 30-65.

On average, Turkish natives earn 63.1 per cent more than Syrians and an obvious question is whether refugees might be discriminated against by employers. One way to answer this question, at least partially, is by means of a so-called wage regression. This tool allows us to control for job-related and personal characteristics that might influence hourly wages. For example, Syrians' low wages might be partly explained by the fact that they work informally. Some of the variables used in this exercise include the gender, age ${ }^{24}$ and educational attainment of the person. Additionally, job-related variables like the economic activity, occupation and the formality of work arrangements are also taken into account ${ }^{25}$.

Table: 5

Minimum Wage Compliance

\begin{tabular}{|c|c|c|c|c|}
\hline & & \multicolumn{3}{|c|}{ Hourly Earnings } \\
\hline Group & Hourly M.W. & Below 95\% & $95 \%$ - $105 \%$ & Above 105\% \\
\hline All & \multirow{3}{*}{7.17} & 75.4 & 7.7 & 16.9 \\
\cline { 1 - 4 } Men & & 76.4 & 7.7 & 15.8 \\
\cline { 3 - 5 } Women & & 68.7 & 7.4 & 23.9 \\
\hline
\end{tabular}

Source: HLFS 2017 and author's own calculations. Notes: The table shows shows the group-specific percentage of Syrian employees earning below (<95\%) at or around (95\%-105\%) and above (>105\%) the net hourly minimum wage. The minimum wage is expressed in nominal TRY of 2017.

Results from the wage regression are mixed. On the one hand, we find that informal Syrian employees are paid the same as Turkish informal employees -other things being held constant. On the other hand, the few Syrians working formally earn, on average, 10 per cent less than Turkish citizens with similar characteristics. An even bigger loss, though, is faced by highly educated Syrians who work without a work permit. By using a modified specification ${ }^{26}$ we can calculate the 'return to schooling' -the increase in wages due to an increase in the number of years spent in school- for Syrian $s^{27}$ as well as for formal and

24 Including a square term to proxy for potential labour market experience.

25 A complete accounting of the variables included in the regression goes as follows: 11 economic activities (ISIC rev.4), 9 occupations (ISCO-08), company size, public/private ownership, place where the business takes place, formality of work arrangements, a binary variable for being a Syrian refugee and an interaction term bringing formal and Syrian refugees together. The adjusted $R^{2}$ of the regression is 0.5852 .

26 The modification consists of interactions between binary variables with the highest degree achieved and a dummy for, respectively, formal and informal Turkish employees.

27 We do not distinguish between formal and informal Syrian refugees due to the small number of observations among the former group. 
informal Turkish employees. The results, which may be seen in Figure 11, show for each of the three groups under analysis the percentage increase in earnings achieved by a higher level of educational attainment. It should be noted that the comparison is in relative terms, and the return to schooling of Syrian refugees with no formal education is set to 0 .

We find that Syrians with tertiary degrees are punished twice in the labour market. First for not having a work permit and then for their degrees not being recognized. Indeed, Syrians' return to a college degree is 5 times smaller than the one received by a formal Turkish native. As expected, the informality of work arrangements halves the return to college, from 76.9 per cent to the 37.1 per cent actually enjoyed by Turkish informal workers. However, it looks like employers of informal employees also value differently the knowledge brought by Turks and Syrians, with the latter obtaining a mere 14.6 per cent increase in their hourly wages for their degrees. This would, perhaps, give support to the importance of job-market signals as pioneered by Spence (1973) in contrast to the importance attached to sheer human capital.

Figure: 11

\section{Return to Schooling by Formality of Work Arrangements and Nationality}

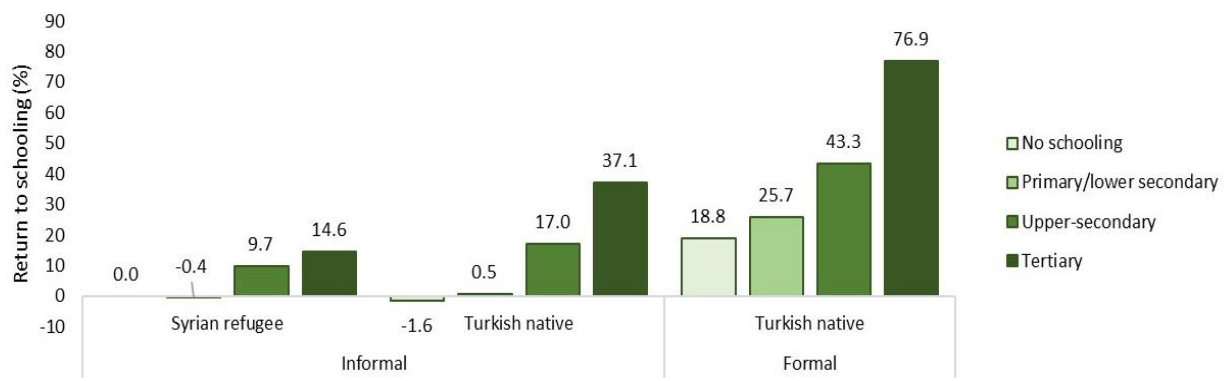

Source: 2017 HLFS and author's own calculations. Notes: The figure shows the return to schooling (additional salary earned for having spent more years in education) of three groups, informal Syrian employees, informal Turkish employees and formal Turkish employees. Results are extracted from a (log) wage regression where controls for sex, age, occupation, economic activity, firm size, type of workplace and ownership (public/private) are also included. Syrian refugees with no schooling constitute the reference point and their return is set to zero.

\section{Conclusion}

A few years ago, Turkey opened its doors to Syrian refugees, allowing them to escape from a civil war and granting them, among other basic social services, free access to healthcare and the right to stay indefinitely. As a result, more than 3 million Syrians settled in Turkey, found employment and started businesses in an effort to normalise, once again, their lives.

In spite of the tremendous efforts made by Turkey in ameliorating the effects of one of the largest refugee crisis, there still remains considerable challenges ahead. Some of these are long-term and represented by a broad-base population pyramid of potentially loweducated individuals. The combination of low-skilled workers and a world of work 
increasingly dominated by the forces of globalization and digitization incurs the risk of developing a new underclass whose reversal might take several generations. As new technologies come along, it is more important than ever that workers keep pace with new developments. Accordingly, the 22.0 per cent of 15-year-old Syrians attending school is, by any reckoning, insufficient to guarantee a successful future for young refugees.

There are also short-term challenges with respect to the provision of decent work that need to be tackled even in the event of an early return of refugees to their homeland. This research have determined working conditions' deficits in relation to excessive working hours, non-compliance of the minimum wage legislation and denial of rights at work derived from the absence of work permits. The consequences of these deficits on Syrians' well-being include an increased risk of falling into poverty, social exclusion and marginalisation. For instance, the Confederation of Turkish Trade Unions (Türk-İş) defined the hunger threshold $^{28}$ at 1,529 TRY, but the average monthly salary falls short at 1,302 TRY. This poses a limitation to families with a single income earner and would indirectly encourage children to access the labour market at an early age.

The role of education as a social lift is also seriously limited in the current context. Not only might young Syrians not have incentives to remain in education, but those with university degrees also find themselves unable to benefit from their studies. In particular, this research finds that informal work arrangements together with the lack of recognition of prior learning is lowering the earnings that these individuals derive from their university degrees by a factor of 5 in comparison to similar Turkish citizens.

Irrespective of the work-life aspect under analysis, it should not be forgotten that the root cause of low wages and excessive working hours is informality. Given the low number of Syrian refugees who have been given a work permit, and with the objective of providing better working conditions as well as supporting the Social Security Institute's operations, some additional measures might be due. At a minimum, effective guidance should be provided to both Syrian workers and employers. Social security rights and obligations should be well-explained, and information activities should be organised within this scope. Moreover, increasing the awareness of company's accountants, allowing extra time to employers before registering refugees and/or making the application procedure simpler could increase the number of applications for a work permit.

Even though Syrian refugees face several challenges in their quest to decent work, it should not be forgotten that the arrival of several million refugees has had an impact that goes beyond this group's living conditions. Informality rates have increased in several economic sectors as a result of employing Syrians without a work permit. Moreover, it 
cannot be discarded that refugees are crowding out natives from informal jobs -especially in the textile and garment industries. This may happen in spite of the occupations held by refugees being, to an extent, complementing those of informal Turkish workers. Last but not least, informal work arrangements are also damaging to the social security institution (SSI) of Turkey and they hamper the capacity of the institution to provide much needed support.

\section{References}

Bircan, T. \& U. Sunata (2015), "Educational assessment of Syrian refugees in Turkey", Migration Letters, 12(3), 226-237.

Ceritoğlu, E. \& B. Gürcihan-Yüncüler \& H. Torun \& S. Tümen (2015), “The impact of Syrian refugees on natives' labor market outcomes in Turkey: Evidence from a quasiexperimental design", IZA Discussion Paper Series, No. 9348.

Del Carpio, X.V. \& M. Wagner (2015), "The impact of Syrian refugees on the Turkish labor market”, Policy Research Working Paper 7402, World Bank Group, August 2015.

Erdoğan, M. (2017), "Syrians barometer - 2017: A framework for achieving social cohesion with Syrians in Turkey", Executive summary.

İçduygu, A. \& E. Diker (2017), "Labor market integration of Syrian refugees in Turkey: From refugees to settlers", The Journal of Migration Studies, 3(1), 12-35.

İçduygu, A. \& E. Millet (2016), "Syrian refugees in Turkey: Insecure lives in an environment of pseudo-integration", Koç University Working Paper 13, August 2016.

Kaymaz, T. \& O. Kadboy (2016), "Syrians in turkey - the economics of integration", Alsharq Forum, Expert Brief.

Konun, B.B. \& S. Tümen (2016), "Immigration and prices: Quasi-experimental evidence from Syrian refugees in Turkey", Central Bank of Turkey Working Paper No 16/01.

ORSAM (2015), "Effects of the Syrian refugees on Turkey", Ortadoğu Stratejik Araştırmalar Merkezi, Report No 195, January 2015.

Pinedo-Caro, L. (2019a), "Identifying Syrian refugees in Turkish microdata", ILO Research Department Working Paper No 46.

Pinedo-Caro, L. (2019b), "The impact of Syrian refugees: The costs and benefits of informal employment", unpublished manuscript.

Spence, M. (1973), "Job market signalling”, The Quarterly Journal of Economics, 87(3), 355-374.

Tümen, S. (2016), "The economic impact of Syrian refugees on host countries: Quasi-experimental evidence from Turkey", American Economic Review, 106(5), 456-460.

Uçak, S. \& K. Raman (2017), “Another side of the story: A market assessment of Syrian SMEs in Turkey”, Building Markets.

UNHCR (2014), "Regional refugee and resilience plan 2015-2016 in response to the Syria crisis", $3 P R$. 